- криза духовності і деформація традиційних норм сумісного життя людей (чесності, порядності, відповідальності, справедливості, співпереживання чужого горя тощо).

- різноманітні намагання кардинально переглянути і зруйнувати базові засади традиційної сім’'і.

\title{
Література:
}

1. Павлов В. Л., Савельєва М. Ю., Суходуб Т. Д. Феномен кризи: погляд з позицій філософіï. International scientific and practical conference «Political science, philosophy, history and sociology: development areas and trends in Ukraine and EU». - Wloclawek, Republic of Poland, October 30-31, Kuyavian University in Wloclawek, 2020. - Wloclawek: Izdevnieciba «Baltija Publishing», 2020. - C. 15-16.

DOI https://doi.org/10.30525/978-9934-26-079-7-20

\section{ПРОЦЕС ЗЛИТТЯ ЧОЛОВІЧОГО І ЖІНОЧОГО НАЧАЛ ЯК НАБУТТЯ ЛЮДСТВОМ ЯКІСНО НОВОГО СТАНУ ЧЕРЕЗ ПРИЗМУ ГЛОБАЛІЗАЦІЇ}

\section{Тімашова В. М.}

доктор політичних наук, доцент, професор кафедри публічного управління та міжнародних відносин Національного педагогічного університету імені М. П. Драгоманова м. Київ, Україна

Якщо підійти до явищ модернізму і постмодернізму з психологічної точки зору, то побачимо, що в основі модернізму явно простежується чоловіче начало, характеристиками якого $є$ воля до влади і любов до порядку, пунктуальність і працездатність, кар'єризм та ієрархічність, прагнення домінувати тощо. Ці якості маскулінності втілюються в раціональному Его.

Постмодернізм, на відміну від модернізму, відрізняється характеристиками, що втілюють жіноче начало, такими, як емоційність, фрагментарність свідомості, суперечливість, нестабільність, чуйність, розвинена фантазія, заперечення волі, іррраціоналізм і т. п.

Прагнення маскулінної цивілізації взяти під контроль всю ойкумену шляхом створення ідеальної уніполярної ієрархічної системи неможливо в принципі, оскільки для цього вона повинна включати в себе безліч варіантів існування і розвитку й передбачити безліч факторів, що впливають ззовні, - економічних, природних, біологічних тощо. 
Створення такого ідеального світу можливе лише в теорії, тому різні системи, тобто, нації, спільноти, цивілізації в умовах обмеженості ресурсів для розвитку без взаємного знищення повинні вступати в конструктивну взаємодію одне 3 одним, - вважає С. Удовик $[1$, c. 362]. Вони починають вчитися дивитися на себе очима Іншого і прагнуть пізнати інші системи цінностей - тобто системи архетипів, а це можливо лише при подальшому розвитку свідомості.

Карл Юнг назвав цей процес індивідуаиією, тобто процесом, коли Его зливається з Самістю і відбувається злиття чоловічого і жіночого протилежностей, що забезпечується трансцендентальною функцією.

Метою процесу індивідуації є набуття Самості, тобто центру цілісної особистості, яка являє собою сукупність свідомості та підсвідомого. Самість в середньовічній європейській міфології уособлювалася чашею Грааля. Набуття Самости по суті відображає інтеграцію світу мирського і світу духовного чи трансцендентального, в результаті чого долається подвійність людського існування і протиріччя між світами, набувається психічна рівновага і цілісність особистості.

Набуття самості або балансу між двома світами можна досягти двома шляхами - через світ фізичний чи світ духовний. До прикладу, першим шляхом пішла китайська цивілізація, по другому буддистська. Способів досягнення балансу між духовним і матеріальним безліч, і кожна цивілізація пропонує свій - єдино вірний на іiі думку. Проблема полягає в тому, щоб, розвиваючись в одному світі, не забувати про існування іншого.

Таким чином, світ через визнання і пізнання Іншого може перейти від екстенсивного розвитку до розвитку інтенсивного, тобто до моделі сталого розвитку в умовах відновлювальної ресурсної системи, інакше відбувається регрес і світ заново, під впливом архетипів, починає 3 хаосу (різноманіття) формувати нові конфігурації біологічних систем, організмів і соціальних спільнот, - підсумовує С. Удовик [Там само, с. 363].

«Еволюція йде від хаотичної множини до організованої не інакше, як через попередній розвиток самобутності кожного окремого члена», - стверджує В. Шмаков [2, с. 88]. Індивідуальність особистості проявляється в її здатності до творчої організації. I чим вище ступінь еволюції, досягнута особистістю, тим більше вона впливає на іiі подальший перебіг.

Сьогодні в Західній Свропі набирають силу деструктивні тенденції: паралельно зі зростанням кількості самоактуалізованих особистостей ще більш швидкими темпами зростає число людей із різного роду психогенними порушеннями. Злиття маскулінного i феменінного (в психічному плані) заміщається їх змішуванням у фізичному світі, що призводить до зростання гомосексуалізму, лесбіянства, бісексуалізму, 
трансвестизму. Тобто, фактично, відбувається деградація суспільства через втрату статевих ознак і знеособлення.

У сучасному світі навіть в більшості демократичних країн пріоритет віддається чоловікам. Може здатися, що це - данина традиціям, але, як вже зазначалося, причини такого стану речей лежать у психології - у переважаючому типі свідомості. Адже чоловіче (маскулінне) і жіноче (фемінінне) начала - це психологічна основоположна пара протилежностей, з одного боку нерозривно пов'язаних, а 3 другого - таких, що знаходяться в опозиції один до одного. Ця пара не має відношення до гендерних теорій і не пов'язана зі статевими відмінностями, а символічно виражає ментальні характеристики людини.

Свого часу цю теорію розвинув К. Юнг, а найбільш чітке визначення цієї пари дав Е. Нойманн: «Коли ми говоримо, що чоловіча або жіноча домінанта проявляється більш сильно на певних стадіях, або в деяких культурах, або типах особистості, то це - психологічне твердження, яке не повинно бути зведене до біологічних або соціологічних понять. Символізм «чоловічого» і «жіночого» прототипний, а, значить, трансперсональний. У різних культурах його помилково переносять на особистості, тобто нібито вони є носіями його властивостей. Насправді кожен індивід $€$ психологічним гібридом. Навіть статевий символізм не може починатися з особистості, оскільки він первинний по відношенню до неї. I навпаки, одна зі складностей психології полягає в тому, що в усіх культурах цілісність особистості порушується, коли ії ототожнюють 3 чоловічною або жіночої стороною символічного принципу» [3, c. 17-18].

Цікавою в цьому аспекті є думка Л. Васильєвої, яка пише, що «у першій главі «Битія» Бог створює чоловіка по власному образу i подобію у двох рівновеликих іпостасях: Чоловіка та Жінку. Вже у другій главі Бог створює лише чоловіка, а потім 3 ребра чоловіка створює жінку... Чоловік і його помічниця жінка співіснують в історії за правилом другої глави, а рівновелика Чоловіку Жінка, створена Богом на Шостий день, кудись зникла. Чи може бути, ставить запитання авторка, - що іiі зникнення і породило болісну, незворотну, таку, що веде людство у прірву, дисгармонію нашої цивілізації?» [4, с. 8-9].

При найближчому розгляді структури цивілізації можемо побачити, що в патріархальної цивілізації може на рівні сім’ї домінувати фемінінне начало, а в демократичних, зокрема, скандинавських країнах, де все більшу роль відіграють жінки, насправді домінує маскулінний початок. Поєднання або переважання на різних соціальних рівнях цих характеристик може чинити визначальний вплив на розвиток не тільки країни, а й власне цивілізації. 
Сфера дії глобалізації охоплює не тільки економічний і політичний простори, а й соціокультурний. Виходячи 3 наведених положень психології, С. Удовик визначає глобалізацію як процес злиття чоловічого і жіночого начала, тобто набуття людством якісно нового стану-Самості або повноти існування [1, с. 367].

Вочевидь, цей процес перебуває у самій початковій фазі. У найбільш розвинених цивілізаціях відбулося пізнання чоловічого начала (маскулінна цивілізація), відбувається пізнання жіночого начала (постструктуралізм). Разом із ними у світі присутні традиційні суспільства 3 архаїчною культурою та інфантильним соціумом. Можна сподіватися на те, що в разі успішного процесу злиття чоловічого i жіночого начал у християнській цивілізації відбудеться прискорений розвиток інших цивілізацій: східно-європейської (інфантильної), ісламської (архаїчної). Процес злиття цих начал може статися під впливом західної цивілізації і між японською (фемінінно-естетичною) та китайською конфуціанською (маскулінно-енергетичною).

\section{Література:}

1. Удовик С. Л. Глобализация: семиотические подходы. Москва: «Рефл-бук»; Киев: Ваклер. 2002. 480 с.

2. Шмаков В. Закон синархии учение о двойственной иерархии монад и множеств. Киев: София, 1994. 320 с.

3. Нойманн Эрик. Происхождение и развитие сознания. Москва: Рефл-бук; Киев: Ваклер, 1998. 464 с.

4. Васильева Л. Н. Жены русской короны. Книга 1. Москва: Атлантида XXI век, 1999. 416 с. 